\title{
Overview on Practical Teaching Base
}

\author{
Yangli Li \\ Xi'an International University, Xi'an, 710077, China
}

Keywords: Practical teaching, Base, Colleges and universities

\begin{abstract}
. practical teaching is an indispensable constituent part running through the training process of applied college talents as well as an important means for students to understand theoretical knowledge, develop active learning spirit and exercise comprehensive quality and ability. Practical teaching base is an important condition for realizing the training of applied talents.
\end{abstract}

\section{Basic concept of practical teaching base}

Practical teaching has special effects on the improvement of students' comprehensive quality and the training of their spirit of innovation and practical ability. Practical teaching base refers to a relatively stable site with a certain scale for students' participation in practical teaching activities. Practical teaching base provides necessary conditions and services for students to complete experiment, probation, internship, practical training, graduation thesis (design) and social practical activities. It is a basic condition of practical teaching and its construction and management directly concern the quality of practical teaching.

Practical teaching base first should have a certain scale. Practical teaching base is established to meet the demand of practical teaching. Any major has a certain number of students. It is especially true in the current period with massification of higher education. Therefore, both on-campus and off-campus practical teaching bases must keep a certain scale. A site without a certain scale which can only receive several students for internship and practical teaching cannot be counted as a real practical teaching base.

Practical teaching base must have relative stability. Both on-campus and off-campus practical teaching bases should undertake practical teaching tasks within a certain period of time. Most colleges and universities set three years as the minimum time to guarantee the stability of practical teaching base. Reasons to guarantee the stability of practical teaching base include the following: first, practical teaching is stable, which is circulating routine work in college teaching with strong regularity. The instability of practical teaching base will produce great influence on normal implementation of practical teaching. Second, the construction of practical teaching base requires fund input and preparation of various conditions. If the stability of practical teaching base is not maintained, teaching management costs will increase.

Practical teaching base must have specific tasks. The construction of any practical teaching base must have specific objectives and tasks. Due to different majors, practical teaching base undertakes different teaching tasks. For example, educational practice bases of normal colleges - elementary and secondary schools undertake such tasks as teaching internship and probation. Medical practice bases of medical colleges - teaching hospitals undertake such tasks as medical education internship and probation. Internship farms of agricultural colleges and universities undertake such tasks as internship and probation of students majoring in agriculture. Most practical teaching bases without specific teaching task, especially off-campus practical teaching base, only hang out a sign for making up the number and cannot play a due role in talent training process.

Practical teaching base must allow students to receive training about practical abilities. It is different from classroom, laboratory and specific workplace. With specific work environment, instruments and equipment and training facilities, it is a comprehensive training site for training students' professional abilities and occupation abilities. Practical teaching base fully reflects normalization, scientificalness and effectiveness with the training of students' technical application ability and comprehensive quality as gist, the advanced level of industrial science and technology and 
social development as standard and the talent training orientation and actual demands of majors as basis. It is consistent with production application, technical development, management and service etc. A true and effective talent training environment is formed, thus providing students with a sense of being personally on the scene, allowing students to receive systematic and standard professional and post ability training and improving their abilities of knowledge application and practical application.

\section{Classification of practical teaching base}

There are different types of practical teaching bases for applied undergraduate colleges and universities. As per location, practical teaching bases can be divided into on-campus and off-campus ones; as per the number of disciplines included, they can be divided into single-discipline and multi-discipline comprehensive ones; as per nature, they can be divided into teaching-type, teaching research-type and production teaching-type practical teaching bases. Only on-campus and off-campus practical teaching bases are analyzed briefly.

\section{On-campus practical teaching base}

Applied undergraduate colleges and universities have heavy practical teaching tasks. To guarantee the completion of practical teaching tasks, it is required to establish a stable and high-quality on-campus practice base and make it a multi-functional base integrating teaching, scientific research and practice. On-campus practical teaching base is a practical teaching site established by each teaching unit according to features of majors with dependence on on-campus experimental center (complex laboratory) and institutions upon the approval of school.

Compared to off-campus practical teaching base, on-campus practical teaching base has the following advantages:

(1) Convenience. As on-campus practical teaching base is established on campus, it is close to students' classroom teaching. Therefore, it is very convenient to conduct skill training. In particular for skill training items with long time or certain time interval, it is more convenient and easy to arrange in on-campus practical teaching base.

(2) Strong guarantee. Most on-campus practical teaching bases are invested by school. Internship and probation equipment can be added through purchase at any time according to the need of practical teaching. Internship and probation items can be set up according to the need of practical teaching. When it is necessary to adjust the teaching program due to special circumstances or practical teaching tasks cannot be assigned due to any reason of on-campus practical teaching base, schools can easily adjust the teaching program appropriately so as to guarantee the need of practical teaching effectively.

(3) Convenience for management and control. On-campus practical teaching base can make a long-term plan for base construction according to the need of practical teaching and strengthen base construction in a purposeful, planned and organized way. Meanwhile, the construction of practical teaching base can be adjusted appropriately according to major setting and changes of teaching tasks so as to better meet the demand of practical teaching.

\section{Off-campus practical teaching base}

Off-campus practical teaching base refers to a relatively stable site with a certain scale established by relevant school department and teaching unit according to different features of majors and disciplines with the selection of enterprises, business units and scientific research institutions meeting corresponding practical teaching conditions based on equal consultation, which can meet the demand of practical teaching links such as undergraduates' internship, training, social practice and innovation. Off-campus practical teaching base is an important site for practical teaching and an important approach for the improvement of students' occupational quality and professional abilities and the formation of their professional ethics as well as an important link in the realization of talent training objectives by applied undergraduate colleges and universities. It plays a vital role in the training of students' practical abilities, spirit of innovation and entrepreneurship. 
Compared to on-campus practical teaching base, off-campus practical teaching base has the following advantages:

(1) Talent training integrates with social needs more easily. Most off-campus practical teaching bases are hospitals, relevant government sectors, enterprises, business units and scientific research institutions. Such organizations are also employers. Students can take an internship or probation in such organizations and directly understand their requirements for the quality of applied talents. Schools also adjust talent training link reasonably according to social needs. Therefore, off-campus practical teaching base is the bridge and link of contact between applied undergraduate colleges and universities and the society.

(2) The environment of practical skill training is truer. As off-campus practical teaching base is a real production site, skill training of students in the practical teaching base is an important link in production process. Therefore, the environment of practical skill training received by students in off-campus practical teaching base is truer.

(3) Functions are more comprehensive. Off-campus practical teaching base can provide students with basic skill training, but more importantly can train students' design and development abilities and improve their spirit of innovation. Off-campus practical teaching base is both a teaching and scientific research base and new technology and product research and development base. Such composite base integrating industry, university and research integrates teaching, scientific research and technologies and allows students to attend scientific research activities, touch new technologies, products and methods and understand some latest development trends of the discipline and industry early or find some objectives of future research and work direction and enlighten innovation. This not only improves students' professional basic skills, but also trains their design and development abilities and strengthens their spirit and ability of innovation. It plays a comprehensive role in the improvement of their comprehensive qualities.

\section{Functions of practical teaching base}

Practical teaching base is an important site and effective channel for applied colleges and universities to train applied talents. It has vital functions in teaching, scientific research and service for the society.

\section{Improve the quality of applied talent training}

Its function of improving the quality of applied talent training is determined by objectives and mode of talent training of applied undergraduate colleges and universities. The training objective of applied undergraduate colleges and universities is to train senior applied professional talents adapting to needs of production, management and service for national and local economic social development. The most important feature of such applied talents is that they have strong ability of theoretical application and practical abilities of working in the front line of production, management and service. Such practical abilities are not trained simply by theoretical teaching in class. More importantly, they depend on practical teaching. To emphasize the training of students' practical abilities, applied undergraduate colleges and universities must form their unique talent training mode different from research-type universities. In the specific talent training mode of applied undergraduate colleges and universities, practical teaching base meeting the demand of students' internship and probation must be established so as to train students' practical abilities and spirit of innovation. Practical teaching base is an important constituent part of talent training mode of applied undergraduate colleges and universities, which provides important conditions for the implementation of each link of practical teaching. It is also an important site for students to transform theoretical knowledge into actual application and obtain practical skills. Internship and probation in practical teaching base allow students to improve their professional skills and practical abilities, train the spirit of innovation, strengthen the awareness of cooperation and team, increase understandings of the society and obtain experience of future career. 


\section{Implement industry-university-research cooperation}

Practical teaching base is both a teaching base and industry-university-research cooperation base. Industry-university-research cooperation is an effective approach for applied undergraduate colleges and universities to train applied talents. Students practice and explore in learning and learn in practice and exploration through industry-university-research cooperation. Their comprehensive qualities are improved. Industry-university-research cooperation is also an important approach for serving the society, through which relevant factories and enterprises obtain advanced technical support from schools, develop new products and technologies, exploit new service fields and market and create new performance constantly. Practical teaching base is the platform for industry-university-research cooperation, on which enterprise demands represent social demands, which not only raise requirements for the quality of talent training, but also indicate the development direction of new products and technologies. Colleges and universities complete talent training tasks on this platform, undertake the function of serving the society and meanwhile improve their own scientific research level.

\section{Expand employment space of students}

Employment is the essence of people's livelihood as well as an important orientation of talent training of applied undergraduate colleges and universities. Applied undergraduate colleges and universities hold a large proportion in Chinese colleges and universities. Undergraduate applied talents aiming at production, management and service constitute a huge group of employment. Teaching quality of applied undergraduate colleges and universities and students' ability of social adaptation determine the employment rate of students to a great extent. The exploitation of multiple employment channels and the establishment of a stable employment base are important measures for improving employment rate. As off-campus practical teaching bases receive college students for internship and probation for a long time and internship and probation items are closely related to actual production of enterprises, skill training received by students in the base is equal to post training. Therefore, students taking an internship or probation in practical teaching base meet the recruitment demand of enterprises. Therefore, practical teaching base is not only a teaching site, but also an employment site of students; it is both a teaching site and employment site. Students' employment space is expanded.

\section{Improve quality of college teachers}

The training of high-quality applied talents is a basic task of applied undergraduate colleges and universities. To complete the task, there must be a batch of instructors with high theoretical level and strong professional practical abilities. According to the current status of applied undergraduate colleges and universities, most teachers move from one school to another. The only difference is learning level or the transformation from students to teachers. They also have inadequate practical abilities. Therefore, they can hardly complete the task of training students with strong practical abilities. It is urgent for applied undergraduate colleges and universities to improve teachers' practical abilities. On-campus and off-campus practical teaching bases established by applied undergraduate colleges and universities provide a site for improving practical skills of both students and teachers. Teachers' process of guiding students in practical teaching base is also a process of learning and exercise. In some sense, it is supplementation or retraining for applied undergraduate teachers, especially young teachers. Moreover, applied undergraduate colleges and universities also invite technical experts, management experts and skillful craftsmen with rich practical experience and enthusiasm about education as external teachers through the construction unit of off-campus practical teaching base so as to improve their teaching staff structure, form a “double-type” teaching group and improve the quality of education and teaching effectively. 


\section{Acknowledgement}

Fund program: Special Scientific Research Planning Project of Shaanxi Education Department, Project No.14JK2103; Project name: Study on Integration of Outdoor Training into Educational Practical Course System for Employment and Entrepreneurship of College Students.

\section{References}

[1] Liu Min. Study on Status of Implementation of Outdoor Training Course of Regular Colleges and Universities in Shanxi and Countermeasures. Shanxi Normal University, 2014.

[2] Guo Huajun. Study on Status of Implementation of Outdoor Training in College Sports Course. Tourism Overview (second half of the month), 2013,10:220-221.

[3] Yang Xiyong. Study on Status of Implementation of Outdoor Exercise in Colleges and Universities in Shaanxi. Contemporary Sports Technology, 2013,36:163+165. 